\title{
Election Related Violence in Nigeria: Perspectives, Policies and Prospects
}

\author{
Gamaliel Ajoku \\ Independent National Electoral Commission \\ Plot 436 Zambezi Crescent, Maitama District, FCT Abuja, Nigeria
}

\begin{abstract}
Electoral Related Violence (ERV) is one of the major problems bedevilling the Nigerian democratic system with severe outcomes such as the loss of lives and property, violation of the rule of law, weak democratic governments and poor leadership among others. This study was carried out with the main aim of examining the perspectives, policies and prospects of ERV in Nigeria. The study explored the various dimensions of ERV, the laws that are set up to ensure elections are peaceful and finally, the means of ensuring that ERV is prevented or controlled by the implementation of the relevant laws. The mixed methods research technique was utilized for the gathering of data for this study; both qualitative and quantitative research methods were used. A total of 500 randomly selected electoral workers from the Independent National Electoral Commission (INEC) were employed for the survey, the respondents were issued questionnaires and also interviewed. The perspectives of ERV that emerged from the study include the provision of a viable health policy for electoral workers, use of technology, improved security measures, independence of electoral bodies, threats and kidnapping, education and training of electoral staff, vote buying and public office attraction. The study also showed that there were already some very important laws and acts contained in the electoral act and the constitution that were designed to address various types of electoral malpractice effectively, however, there have been a very poor implementation of the essential laws that are supposed to act as punitive measures for those found guilty of breaching electoral laws as well acting as dissuading factors for those with criminal intent.The Nigerian electoral law dictates that the relevant punitive measures for electoral malpractice include fines, conviction or both. After exploring the perspectives and policies addressing ERV, this study recommends the adoption of modern communication technologies for election monitoring and exchange of information, strengthening of the security apparatus, full implementation of all relevant existing laws and electoral acts capable of reducing ERV by punishment, provision of relevant health and welfare packages for electoral workers. The study further suggests that the transparency of electoral bodies and provision of adequate education for the masses should be effected as some of the approaches that can be adopted as measures for the reduction or total elimination of ERV among other measures.
\end{abstract}

Keywords: Electoral Related Violence, Perspectives, Policies, Prospects

DOI: $10.7176 / \mathrm{DCS} / 12-1-04$

Publication date: January $31^{\text {st }} 2022$

\section{Introduction}

Democracy as a system of government is unique and its use has spread to most countries of the world. Asides the core feature of ensuring that every individual is adequately represented in government as well as the decision making process, democracy also ensures the concepts of fundamental human rights and freedom are accorded to the citizens of a democratic nation among other benefits. Boonlue (2014), explains that democracy as a system of government ensures the protection of the lives and rights of its citizens. He further expatiated that protection of the freedom, life and rights of citizens by the democratic government of a country ensures for more participation in the government by the citizens of a country practising the democratic system of government. Warren (1999) in agreement with Boonlue (2014), explained that one of the major reasons for the popularity of democracy as a system of government is the provision of the rule of law, which is a major cornerstone of democracy. The rule of law in democracies ensures that all are equal and accountable to the law; it also ensures that the rights of the people are protected, consequently, the adequate representation of citizens in the democratic system is one of the unique features that have made democracy more attractive and effective as a system of government. He further added that the availability of various levels of representation accessible to citizens tend to provide a certain relationship between the people and the government as well as ensuring that the benefits of the democracy are available to all and sundry, furthermore, the democratic system of government also ensures adequate feedbacks as those elected are supposed to convey the needs of the people to the government thereby ensuring that their needs are met and concerns addressed . (Boonlue, 2014; Warren, 1999; Castiglione and Warren, 2006).

Democracy as a system of government has gained popularity due to its unique pattern of selecting leaders by their popularity via the electoral process. Thomassen and Denters (2010) argues that democracy tends to truly reflect the choices of the people, this is because everyone eligible for voting has a right to vote their choice candidates during elections. Adequate representation of the people by the democratic system of government is supposed to lead to the provision of relevant policies that are key to the welfare of the masses however the 
emergence of unpopular candidates from elections in some cases tend to undermine the concept of democracy. One of the most popular means of influencing elections to favour of certain candidates is the use of violence which is typically employed before, during and/or after elections. Verjee, Kwaja, and Onubogu (2018) have explained that the use of violence as a tool for controlling the outcome of elections is quite popular amongst emerging democracies especially in developing countries. Various forms of violence have been employed to achieve predictable outcomes during elections. They further opined that one of the major techniques employed in developing countries is the use of pre election violence to deter voters from turning up for the voting process. In most cases, this strategy is employed in areas where the opposition is popular thereby ensuring low voter turnout which eventually affects the eventual outcome of the elections. (Thomassen and Denters, 2010; Verjee, Kwaja, and Onubogu, 2018).

Africa as a continent, is home to various countries, some of which have experienced civil wars, genocides, ethnic cleansing among others. The proliferation of small arms as well as poorly defined borders between countries are some of the factors that aid the increase and circulation of weapons consequently increasing the chances of electoral violence during elections. Kühne (2010), Shenga, C. and Pereira, (2019) agree that a significant population of developing countries have experienced different severities of civil wars and other forms of widespread violence. These experiences tend to lead to weak democratic governments and an increased spate of armed violence among other effects. This weakness is also exhibited during elections which are usually violenceprone mostly due to the availability of arms, desperate political candidates and parties as well as financial insecurity amongst others. Elections in these regions are usually characterized by various levels of violence and a host of electoral malpractices. Electoral violence in such countries also have the possibilities of escalation thereby leading to a relapse or full blown civil wars etc. (Kühne, 2010; Shenga and Pereira, 2019).

\section{Methodology}

Methodology refers to the approaches that were employed in the gathering of information for a particular study. Mamabolo (2009), Pandey and Pandey (2015) asserts that methodology shows the type(s) of research method(s) that was/were adopted in a particular research. The availability of a methodology in a research work helps in showing how much ground was covered, it also helps in showing the sequence of a particular research, design, and samples among others as well as providing a guide for further studies. (Mamabolo, 2009; Pandey and Pandey, 2015).

Mixed methods in research connotes the application of both qualitative and quantitative research methods to a particular study. Some proponents of mixed methods in research; Zachariadis, Scott, and Barrett (2010) have opined that mixed methods have proven to be very useful in the conduct of research because it tends to explore contextual relationships of the subjects in a research. They explained that mixed methods tend to encourage flexibility in research as both research methods are combined to achieve better results. Mixed method in research has become popular among researchers due to the ease at which both methods can be applied to research studies. The use of mixed research in research studies helps in the attainment of a deeper understanding as compared to results obtained from the use of a single method in research. According to Venkatesh, Brown and Bala (2012) "Mixed methods research is an approach that combines quantitative and qualitative research methods in the same research inquiry. Such work can help develop rich insights into various phenomena of interest that cannot be fully understood using only a quantitative or a qualitative method". (Zachariadis, Scott, and Barrett, 2010; Venkatesh, Brown and Bala, 2012).

The application of mixed methods research to studies has continuously increased amongst researchers due to its applicability and versatility to researches in various fields. The results from mixed method research can somewhat be corroborated with the use of triangulation. Torrance (2012) asserted that; "Triangulation has its origins in attempts to validate research findings by generating and comparing different sorts of data, and different respondents' perspectives, on the topic under investigation". The use of mixed methods in research tends to harness the strengths of both qualitative and quantitative methods while compensating for their respective limitations. Mixed methods, due to its flexible application to researches has been adopted by researchers in various areas of study, its use has been proven to bring forth better results as compared to researches where only a single method was utilized. Quantitative result often-times requires some level of qualitative methods for the exploration of the results hence the choice of mixed methods proliferation by researchers (Torrance, 2012; Pluye, and Hong, 2014).

Quantitative research is a unique system of research that utilizes mathematical and statistical investigation or analysis of data. It is usually applied to studies in science related disciplines. Carr (1994) argues that while quantitative research is important and very effective in gathering and processing data from a large number of subjects, it fails to take into cognizance the emotional responses or attributes of respondents. The use of quantitative research ensures for the gathering of relevant data from a large number of respondents, these results and data obtained can be replicated and applied to a larger population. In using quantitative research, the researcher usually requires sufficient time to gather and process data. this could serve as one of the major limitations of qualitative research. Rahman, (2016) agrees that;"'The quantitative findings are likely to be generalized to a whole 
population or sub population because it involves the larger sample which is randomly selected"(Carr, 1994; Rahman, 2016).

Qualitative research is a type of research that seeks to gain insights on a particular topic or research question. The qualitative research tends to explore the understanding and opinions of a subject matter by sampling a seizable number of respondents in the gathering of relevant data. It also makes use of non mathematical or scientific data. Thomas (2003) states that "qualitative research is multi method in focus, resolving an interpretive naturalist approach to its subject matter". Qualitative research uses an array of tools in the gathering of data. These tools tend to explore the views of the selected respondents. Qualitative research seeks to uncover information by asking relevant questions such as where, who, what and why certain things happen. In the use of qualitative research, the researcher is inclined to study the behaviour of the respondent and is able to modify the line of questioning to get specific information from the respondent. Some of the tools used in qualitative research includes interviews and surveys amongst others. Bogdan and Biklen (1997)noted that; "the data in Qualitative research takes the form of words or pictures rather than numbers. Often the descriptive data contains quotations said by informants to illustrate and substantiate the presenting findings"(Thomas, 2003; Bogdan and Biklen, 1997).

\subsection{Results}

\subsubsection{Quantitative Results}

Age Distribution of Respondents

For the purpose of this study, a total of 500 questionnaires were sent out to respondents, 287 questionnaires were returned. The majority of respondents which accounts for about $68 \%$ of the total respondents were Male while the female gender constituted $48 \%$ of the total number of respondents. The age distribution of the respondents showed that majority of the respondents fell within the range of $31-40 y e a r s$, constituting about $38 \%$ of the total respondents. $1 \%$ of the total respondents were less than $20,15 \%$ of the respondents were between $21-30$ years old. While those who fell into the range of $41-50$ made up $36 \%$ of the total population. (Figure 1).

Respondents who Witnessed ERV

From the responses obtained, majority of the respondents have witnessed various forms of ERV. The number of respondents who had witnessed at least one form of electoral violence constituted about $71 \%$ of the total respondents. Amongst those who had witnessed some form of violence, about $69 \%$ were witnesses of politically inclined violence, $7 \%$ had witnessed kidnappings, while $2 \%$ had witnessed assassinations. (Figure 2 ).

\subsubsection{Qualitative Results}

Perspectives

The 4th Respondent said:"You know this can affect family life... for a woman who is always lively and she goes out and experiences this, then she comes home and she's down....she's not herself per say...if there is any assignment again the children will say mummy don't go... it affects the children psychologically too, because it will be like mummy you may go and not come back."

This respondent knows a colleague who was affected by ERV and as a result of this, may decline further electoral assignments. The respondent claims that the ERV has also psychologically affected the family of the colleague who was involved in ERV. The provision of a viable health policy will help in the rehabilitation of affected workers will who have been exposed to ERV. The provision of adequate security could have prevented or controlled the incident.

The 1st Respondent said:"When I first joined the commission...during one of the elections, we had some problems and I think that problem affected me till today, I collapsed and at the hospital I was diagnosed as hypertensive and up till today I have become a hypertensive."

The despondent witnessed a case of ERV shortly after joining the electoral commission. This experience has made the respondent hypertensive and may need to manage the condition for life. The provision of adequate security could have prevented the experience; furthermore, the availability of a sufficient health policy would help in the rehabilitation and treatment of affected electoral staff.

The 9th Respondent said:"The job ...it has been a dangerous adventure....Since the trauma, it has really affected my mental ability...I have been living with it for a while ... you know the trauma, until I was advised to seek counselling... I had been depressed, my mental ability has been at a low ebb, if it used to be 100, it had gone down to 40."

The respondent sees the job as some sort of adventure that has had negative impacts on him psychologically; the respondent has had to undergo counselling to help him manage the trauma as a result of ERV. The respondent also believes that his mental capacity has been reduced as a result of the trauma, a situation that can be better managed with adequate provision of efficient and effective health policies for electoral workers as well as a better security apparatus during elections.

The 5th Respondent said:"I was anxious, I was really terrified it was chilling... there was a moment I thought I would not reach my house I had even called my family to tell them that anything can happen ...because I had seen people being killed it's a mob action, in this kind of things, anything can happen." 
The respondent experienced a case of ERV where people were killed. The resultant fear from that experience made him call his family to inform and prepare them for the possible eventuality of him losing his life to ERV. This scenario as explained by the respondent could have been prevented or better managed with the availability of well trained security personnel whose response to the situation will be faster with the deployment of recent technologies such as close circuit cameras.

The 4th Respondent said:"The trauma is so bad...there was one woman we had, I think she went for the Kogi elections and the experience she had made her vow that she would never ever go for any election activity again ... it was really bad... and there was another woman who was locked up where she was, she couldn't even make phone calls... They took her into the bush ... far into the bush, even now when she talks about it you see goose pimples all over her".

The respondent is an acquaintance of someone who was a victim of electoral violence. The victim has vowed never to participate in any electoral duties henceforth. The respondent also knows another victim who was locked up and denied access to a telephone. She claims she was kidnapped and taken into the bush and still feels traumatized when she talks about her experience. This shows that the provision of adequate security during elections could prevent or reduce the incidence of ERV

The 7th Respondent said:"When I was admin secretary in one of the states in the north, one senatorial candidate... He came to the office bragging, that if the Electoral Officer does not do what he wants, he will kill....he was just bragging... and the Electoral Officer collapsed ... he said he doesn't want to be Electoral Officer ...he said, Oga you don't know this man, if he says something, he will do it".

The respondent was an administrative secretary in one of the Northern States. He experienced a scenario where a senatorial candidate threatened to kill the electoral officer if he doesn't act in his favour during the elections. The respondent claims that the electoral officer collapsed from the threat and was reluctant to act in that capacity because of the threat, he also believes that the senatorial candidate will live up to his threat. The provision of adequate education for the masses, de glamorization of public office and provision of effective security apparatus would have significantly addressed the scenario explained by the respondent.

The 4th Respondent said:“It's not really palatable... it's not good at all, It's terrible they're made to compromise by threats by the politicians...they waylay them with thugs... with guns.... with machetes .... some they even waylay them, kidnap them and make them do what they want."

The respondent believes that the electoral officers are forced to do the biddings of politicians due to threats and intimidation by armed thugs or even kidnapping in some cases. This is largely due to the absence of effective security, as well as the adoption of relevant technologies that will reduce the chances of lives and electoral materials been compromised.

The 2nd Respondent said:"I happened to be in Bauchi for the 2011 election, it was after the presidential elections, it didn't even happen during the elections, they had gone back to their corpers'lodge and the hoodlums attacked them and killed them, nine died on the spot, the tenth person had serious burns...she was later transferred to national hospital where she died."

The respondent who was in Bauchi during the 2011 election was a witness to a case of ERV where corps members who were ad-hoc staffs of INEC were killed or severely injured after the elections, a situation that could have been prevented or better controlled if there was enough electoral education and efficient security.

The 5th Respondent said:"Even the house of the Emir of Zazzau, Emir of Zaria who is the highest traditional ruler in the area was razed to the ground... he too he had to be rescued, he had to leave his palace ...people from the street just ran into his house looking for him. It was really violent ...I saw people being killed... I saw buses being set ablaze... I had to disarm myself and pretend I didn't know anything about elections, all the election materials, I jettisoned them and threw them into the bush because under no circumstance could I be found with them or that will mean the end of my life".

The respondent who is security personnel witnessed the killing of people and destruction of property and had to throw away every electoral paraphernalia on his person to avoid been attacked. He also stated that the palace of the paramount ruler of the area was razed by hoodlums and the Emir had to be rescued. This was largely possible due to the absence or insufficient security.

The 3rd Respondent said: "Your blood pressure may raise... your sugar level may be affected...but if adequate preparations are made, some of these may be prevented."

The respondent is of the opinion that ERV may have some significant medical impacts on the victim; however, if the adequate measures are put in place and effectively implemented, the occurrence of ERV can be prevented. This can be through the full independence of electoral bodies, provision of adequate health policy for electoral staff, provision of adequate education for the electorates during elections and the proper implementation of the electoral acts that penalizes people caught selling or buying votes amongst other measures.

Respondent 11 said: "There is a big need for a health policy in INEC... I just told you that people lost their arms, some people were disfigured, if there was a health policy in place and on ground... it would address this, they would not need to go through the administrative process of writing for assistance, because they don't need 
assistance, it's a must for the commission to do it ...if that policy is in place, all they have to do is to look into the policy and do it...so it's so painful when it is not being done."

The respondent is of the opinion that the availability of a viable health policy for the staff of the electoral body will help in the rehabilitation of the electoral staffs affected by ERV. He also noted that the availability of a viable health policy would reduce the bureaucracy currently encountered by those in need of healthcare and rehabilitation as a result of ERV. The Independence of an electoral body immune to the influence of government and political parties will help in having a well funded and internally health policy that will have less bureaucracy as well as well as meeting the needs of electoral staff timely.

The 1st Respondent said: "I went to the director of admin and I don't know if it is the first time that they are dealing with the matter and finally, for the first time this year they were paid... but what they were paid, I was amazed .... mere 100 thousand ... it was at that time that this Boko Haram thing started...I was aware of many staff that were affected... I knew of someone who had her whole leg removed completely, if you compensate her with 100 thousand... I mean 100 thousand for a deformity?"

The respondent met a director of administration and broached the matter of remuneration of electoral staff with the intention of ensuring that electoral workers were paid on time and adequately. The comments of the respondent indicate that the amount allocated for the electoral workers was not sufficient for the risks involved. Adequate funding of health policies for health workers will help ameliorate the trauma associated with ERV.

The 12th Respondent said: "The psychological trauma...it affects you...a colleague that was rejected by his people due to his role as an electoral officer was under a lot of stress... and that aggravated his high blood pressure, in fact for three months, he wasn't coming to the office."

The respondent claims that a person may be affected by psychological trauma after been exposed to ERV. He claims that a colleague of his was rejected by his people because he was an electoral officer and that has affected him medically and psychologically. The availability of an active health policy would help in the rehabilitation of affected workers.

The 1st Respondent said: "I remember we were conducting an election in Maiduguri... it was at that time that this Boko Haram thing started...I was aware of many staff that were affected... I knew of a someone who had her whole leg removed completely."

The respondent stated that while in Maiduguri on electoral duties, his colleagues were affected, he also knew of a colleague whose leg was amputated. In such cases, electoral workers would require an adequate health policy to help in managing the health conditions as well as counselling and rehabilitation of electoral workers who have been affected by ERV. A well funded health policy for electoral workers will affect the speed and financial coverage available to electoral workers who have been exposed to ERV.

The 5th Respondent said: "Election is a phenomenon of three ingredients, first, there must be education, people must be enlightened people should know the left from the right ...number two people should have a source of earning a living, if I am earning a living I should have a right of independent decision, not that I am earning a living through someone who is earning his living through the government and politics...so economic freedom...so as much as education is important, economic freedom is important...and also the transparency of the system, the process should be as transparent as possible so that everybody will know what is going on...in the southern part of the country, you don't see this as much because people have a means of livelihood."

The respondent believes that three measures have to be out in place to ensure the conduct of free and fair elections as well as reduce the incidence of ERV: adequate education and enlightenment of the masses, financial stability and independence of the electoral bodies. He also noted that financial stability of the electorates will drastically reduce the incidence of vote buying. The adoption of the right electoral policies will help in the achievement of free and fair elections as well as the reduction of ERV.

The 8th Respondent said: "During the 2003 elections in the north east region, I served as the electoral officer of that region... so the commissioner of police came to report that there was the possibility of violence in one particular ...the reason was that the presiding officer had added a zero to the to the score of a particular political party, so the agent had thrashed him."

The respondent who served as an electoral officer in the Northern region of the country witnessed a scenario where a commissioner of police made a complaint of a presiding officer adding an extra zero to the electoral party which resulted in some type of misunderstanding. This type of scenario can be avoided if electoral bodies adopt the use of of electronic voting and collation as it will help in ensuring that the electoral process is free and fair, it will also reduce the incidence of manipulation of electoral results after elections, before the announcement of election results. Adequate provision of well trained security operatives will ensure adequate security during elections.

The 2nd Respondent said: "When you say democracy is expensive, this is the cost...the people that midwife this democracy, they should be made comfortable... There should be a holistic policy on health policy for the commission staff... it should be a document that someone can carry along, not just to lie on the table of the chief executive... it can even be enshrined into the conditions of service." 
The respondent is of the opinion that democracy is expensive and this is because a lot of factors have to be put in place to ensure that elections are successful, credible and peaceful. He believes that health policies for electoral workers should be effective to ensure easy access to healthcare and rehabilitation among others. The provision of an independent source of funding for the electoral bodies will ensure independence of the electoral body as well as adequate planning and disbursement of funds for electoral staff among others.

The 2nd Respondent said: "The commission has made effort... there is provision for insurance for staff and ad-hoc workers...there some healthcare support for staff but this is mainly at the headquarters, so healthcare support needs to be extended to the states."

The respondent notes that some efforts have been made in the area of the provision of health insurance for electoral workers. He further noted that the current insurance scheme only caters for those in the head quarters. He believes that this should be extended to electoral workers working in other states of the country. The provision of a holistic health policy will cater for all electoral staff regardless of their locations.

The 3rd Respondent said: "INEC should take care of their staff welfare before they leave for the election... whatever the staff are entitled to, their claims, let INEC pay them before they reach their station."

This respondent believes that the remuneration for electoral workers be sorted out before they leave to their various areas of deployment for elections. The adequate and timely provision of funding for electoral workers should be enshrined in the electoral policies to ensure that the workers are properly motivated as well as reducing the chances of them been corrupted by electoral candidates who seek to induce electoral workers to work in their favour.

The 9th Respondent said: "They were swooping in to grab the materials, so I turned to the security and told them to hold on because these people were aiming for the material... they held on but they came and pressed him and even tore his uniform... then I turned round and saw a vehicle...I thought that was a rescue vehicle, we ran into it with the police and the orderly and we were saying oh thank God, you people have saved us, but before you know it, they veered off into an un tarred road...moving fast, so I said where are you going, they said, my friend shut up! ...that's when I knew we were captive."

The respondent witnessed an incident where thugs were trying to cart away electoral materials so he asked the security personnel to hold the fort to prevent the carting away and destruction of electoral materials however, the security personnel was overpowered. A vehicle the respondent thought was reinforcement of security and turned to for help ended up been thugs who abducted them. This scenario shows serious inadequacies in the security apparatus that are employed for elections. Relevant implementation of security measures such as; real time surveillance of election centres and the provision of sufficient and well trained security personnel among others have to be adopted in ensuring that polling units, electoral officers and electoral materials are properly safeguarded.

The 6th Respondent said: “...one thing in this job of ours is that once you are perceived to be acting partially ...it is enough, you don't even have to act, perception is as good as reality when it comes to elections, if people perceive that you are going to be partial, they don't even have to wait, they will just start to castigate you... so one has to ensure transparency in everything that he does."

The respondent opines that if adequate measures are taken, electoral workers would perform optimally while delivering free and fair elections. The implementation of relevant policies and technologies will further ensure that some lapses such as prolonged compilation and delayed announcement of results among other actions that tend to reduce the transparency of elections are avoided.

The 8th Respondent said: "There are a lot of things that can be done, including remuneration for the job...It should give you some feeling that you are doing some work that ... and that you are willing to put in your best, because your health is more than just the physical, it includes your housing, your transportation... you know health is a holistic thing."

The respondent believes that proper remuneration of electoral workers will help improve efficiency and motivation among electoral workers in the field.

The 13th Respondent said: "Education can play a big role in enhancing the capability of staff...To be more efficient in the training and this will help in withstanding the stress and risks of election...to some extent we have seen the use of NYSC has helped a lot because of their background, they are able to absorb the training and this will mean that they will follow the procedures."

The respondent believes that education plays a very important role in the prevention and reduction of ERV. He also noted that the proper education and training of electoral workers would likely reduce the incidence of ERV and ensure that the elections are free and fair.

Respondent 1 said: "They really need to work on literacy level... enlightenment level... people need to know what democracy is all about... what roles you need to perform on election day and after the election ... and what to expect from the people you voted in."

The respondent believes that the education of the public on the tents of democracy will ensure that people understand their roles in the electoral process as well as how to demand for good governance from their leaders. 
The 6th Respondent said: "Anywhere that you find that someone feels secure and also assured that in the event that anything happens he will be taken care of, that person will give his 100 percent....It will go a long way in boosting morale and encourage staff to give their best."

The respondent is of the opinion that the provision of adequate security and compensation plan will help spur the electoral workers to motivate and encourage electoral workers.

The 12th Respondent said: "As an electoral officer, you have to be a leader, you have to be a counsellor, and you have to be a mediator ... so on. in most cases, you have to listen, deal with the one that you can deal with....what you do is that you meet with the stakeholders... the party leaders, in the presence of the security agents... you have to be seen as transparent, you tell them what the situation is on the ground and how you intend to address it."

The respondent believes the adequate training of electoral workers will help them multi task effectively thereby resulting to a more efficient and transparent electoral process.

The 1st Respondent said: "The problem of violence occurs as a result of lack of enlightenment...people are not fully aware of their role ...the perception that the office is so lucrative and people want to fight and get into office... You want to win by all means...to be a senator ... a governor... so those things bring up violence and a lack of enlightenment."

The respondent believes that the reduction of public service attraction will in turn reduce the desperation among political candidates to win elections which is one of the main causes of ERV. One of the major ways of reducing public office attraction is the reduction of the remuneration of public office holders.

Summary of Results

The study explored the views of 30 electoral workers, between the ages of 41 and 60, regarding the perspectives, of ERV in Nigeria. From the study the major themes that emerged from the qualitative study include the provision of a viable health policy for electoral workers, use of technology for electoral purposes, improved security measures and independence of electoral bodies, others include threats and kidnapping, education and training of electoral staff, vote buying and public office attraction. These themes represent the various categories of responses from the respondents as regards their experiences and perspectives on ERV in Nigeria.

\section{Discussion}

The use of electoral violence as a tool for influencing elections is common among developing countries especially within the African continent as well as other developing countries in other climes. One of the major reasons why ERV is prevalent in developing countries is the absence of, or ineffective implementation of existing policies that dictates how elections should be conducted. ERV is usually caused by a myriad of factors such as lack of adequate security, lack of effective voter education and training for electoral officers among others. The data provided below represents the findings of this study regarding perspectives, policies and prospects aimed at controlling ERV.

\subsection{Provision of an effective Health Policy for Electoral Workers}

The availability of health policies for agencies, companies and institutions among others helps in ensuring that the health needs of employees are met. The provision also ensures that timely and affordable healthcare is availed the staff in times of medical emergencies. There is a current dearth of information about heath policies exclusively designed for electoral workers, however studies on health policies have shown that health policies are some of the most efficient ways of ensuring access to health services by the citizens of a country. While explaining the effect of a viable health policy for workers and its impact on worker performances, Lundberg, (2009) asserts that in Sweden, the mortality rate among blue collar workers are higher than that of white collar workers who usually have health policies that cater for their health needs, this shows that the availability of effective health policies amongst staff would significantly improve the welfare of staff. Similarly, Franco, Bennett, Kanfer and Stubblebine, (2004) are of the opinion that effective health policies are valid in the motivation of staff, however, they have to be uniquely tailored to fit the health needs of the target recipients as well as having effective implementation strategies. In the Nigerian context, the absence of a health policy the nation's electoral body (INEC) has led to inadequate provision of healthcare and counselling for electoral workers injured or affected in the discharge of their duties during elections. Further alluding to the benefits of a health policy on the performance of workers, Dwomoh, Owusu, and Addo (2013) noted that in the timber industry in Ghana, research showed that the availability of viable health and safety policies improved worker performance and job satisfaction. (Lundberg, 2009 ; Franco, Bennett, Kanfer and Stubblebine, 2004; Dwomoh, Owusu, and Addo, 2013).

\subsection{Technology as a Tool for Reducing ERV}

The application of modern trends of technological innovation has led to a significant improvement of most sectors in the areas of production, marketing, feedbacks and dissemination of information among others. The application of information technology to information gathering has led to the formation of relevant policies required to curb electoral violence. Mancini et al, (2007) pointed out that the use of big data and modern surveillance technologies 
have led to better policing in the City of New York, USA. Bardall, (2013) is in agreement with Mancini et al, (2007) on the importance of modern technology in the formulation of policies aimed at achieving peaceful and transparent elections. She further noted that modern innovations such as the social media has been used to send out gender specific threats as a means of suppressing women during elections, however the positive impacts of technology outweighs the negative. Martin-Shields, (2013) concurs that the use of mobile phones helps in the reduction of ERV. He noted that during the Kenyan elections, the use of mobile phones reduced the incidence of violence as it helped in the timely dissemination of information; he noted that the use of mobile phones helped in the successful dissemination of educational content aimed at sensitizing the public as well as reducing the incidence of electoral violence. In the Nigerian setting, the use of technology has led to the conduct of better elections as well as the gathering of information required for the formulation of electoral policies, measures such as biometric capture and issuance of voters cards has reduced challenges such as multiple voting and identity theft during elections. Further use of technology as prescribed in the Electoral bill awaiting assent will further reduce the current challenges such as election result manipulation while ensuring the full digitization of the electoral process thus increasing the speed of result compilation and computation. (Martin-Shields, 2013 ; Mancini et al,2007; Bardall, 2013).

\subsection{Independence of electoral bodies, Policies and its Effectiveness in reducing ERV}

The activities of electoral bodies, to a large extent determines the level of successes or failures associated with the conduct of elections. The full independence of electoral bodies helps them maintain a non partisan stance which also increases the transparency of elections. The lack of independence of electoral bodies tends to affect their actions as well as the way they are perceived by members of the public. This also means that they can be directly or indirectly controlled by the government of the day and coerced to do their bidding during elections. The policies guiding the set up and activities of the electoral bodies to a large extent influences the way the electoral bodies function, one of the main determinants of the independence of electoral bodies is the mode of financing which has to be structured to be independent of government influence. Lopez-Pintor (2000) believes that the independence of electoral bodies is key in ensuring that they are non partisan, this is mainly because the electoral bodies play a vital role in ensuring that the conduct of elections are free and fair, he argues that while electoral bodies are supposed to be non partisan, they also have to be fair to all parties involved because they play a key role in any country's democracy. Jinadu (1997) agrees with Lopez-Pintor (2000), that electoral bodies have to be independent to achieve their core function of acting in the capacity of the umpire in the electoral process; he also asserted that in Africa, most electoral bodies are not truly independent as they are used by the government of the day to ensure that they win polls and come out successful. He opines that in most cases, the head of the electoral bodies are appointed by the president thus they are mostly loyal to the government of the day; this compromises their position as independent umpires in the democratic process. He believes that for an electoral body to be truly independent, adequate policies have to be put in place to ensure that the electoral bodies have full control of their funds as well as appointment of the chief executives of the electoral bodies. Okello (2006) also believes that complete independence of electoral bodies will likely improve the transparency of elections amongst the people which in turn reduces the chances of a break out of ERV due to perceived partiality on the part of the electoral bodies towards certain political parties or candidates. He stated that in Africa, most electoral bodies have been perceived to be wholly or partially dependent on certain political parties and this has led to the out breaks of ERV in those countries, he also noted that some electoral bodies have started taking measures that will ensure their true independence from the government of the country, he asserts that some of the challenges bedevilling electoral bodies, especially in Africa include lack of adequate resources, inadequate and poorly trained staff and weak legal framework among others. In the Nigerian context, section 158 of the Constitution of the Federal Republic of Nigeria spells out the full independence of INEC and other bodies such as the judiciary and the police among others. The independence of the electoral body is supposed to ensure its non partisanship in the discharge of its duties; however, the electoral body still grapples with transparency issues and a reasonable level of distrust among some citizens who have alleged that the government of the day still exercises some level of influence over the country's main electoral body in the area of key appointments among others. (Lopez-Pintor, 2000; Jinadu, 1997; Okello, 2006).

\subsection{Increased Security as a Way of curbing ERV, Policies and Implementation}

The lack of well trained and adequate security is one of the enabling factors of ERV in any setting. This is mainly due to the possibility of certain political parties or candidates resorting to violence as a mechanism for controlling or influencing election results to their favour. The availability of well trained and effective security presence significantly reduces and controls the incidence of ERV as well as increasing the chances of a free and fair election in a country. Hoglund and Jarstad (2010) opined that the provision of adequate security during elections contributes towards the prevention and control of ERV during elections, however increased security presence could also have some detrimental effects as it may also act as a catalyst for ERV especially in situations where the security 
personnel are used to orchestrate violence with the intent of intimidating voters from exercising their franchise, they further stated that the conversion of the security apparatus by the incumbent or other political parties for selfish interest can be controlled if international security are also on ground during elections as this may limit the possibility of the country's security operatives acting partisan. He further stated that adequate policies can act as a measure for the prevention of impunity by the security operatives in the country. Adolfo, Soderberg Kovacs, Nystrom and Utas (2012) lean to towards Hoglund and Jarstad (2010) on the use of security by some governments in the orchestration of violence, they further noted that some governments purposely increase the presence of security operatives during elections, put a ban on public protests as well as the declaration of a state of emergency aimed at creating an enabling environment for the orchestration of violence during elections. Condra et al (2016) is also of the opinion that security operatives are used by corrupt governments to sway the results of elections to their favour. She also pointed out that that the increased presence of security operatives during the 2010 Afghanistan elections led to low voter turnout of voters for the election exercise. In the Nigerian perspective, the use of soldiers in the conduct of election might have sustained some level of success but the move is still criticized by many who believe that the army shouldn't be used for electoral duties, rather the police whose duty it is to maintain internal law should be used in the provision of security during elections. Sec 29(3) of the Electoral Act 2010 does not specifically stipulate the deployment or non deployment of soldiers for electoral purposes however it stipulates that the commission can request the use of further security if the need arises. The president reserves the right to deploy the armed forces in situations he feels requires their presence. It is believed with proper training, equipment and motivation; the nation's police force can successfully provide adequate security during elections while eliminating the need to involve the army whose major role is to protect the country against external aggressors. (Hoglund and Jarstad, 2010; Soderberg Kovacs, Nystrom and Utas, 2012; Condra et al, 2016).

\subsection{Threats and Kidnapping as tools for ERV, Electoral Act and Implementation.}

The use of threats and kidnappings as tools of ERV used during elections to instil fear while influencing the voting pattern of the electorates has been deemed effective; these methods are mostly directed to both electoral staff and voters during elections. These acts are mostly employed in the areas deemed to be strongholds of the opposition. Apart from its use in the disruption of the electoral process, it has also shown to be effective in reducing the voter turn outs during elections. In citing an instance, Krook and Sanín, (2016) argued that kidnapping rape and murder are some of the tools of violence directed at women in South-East Asia as means of intimidation or suppression during election, they further stated that in some cases the threats are directed to the children of the women been targeted as it has shown to be effective in some cases. Khakee, and Florquin, (2003) agree with Krook and Sanín, (2016), they noted that in Kosovo, the use of threats and kidnappings are mostly directed at women and children during the periods of elections. They noted that similar acts are also experienced in Mexico; threats and kidnappings are employed by family members of women with the intention of intimidating them from participating in elections as voters, electoral workers or even as electoral candidates. Gutiérrez , (2014), in agreement, opined that threats and kidnappings are mostly the used by organized crime organizations to intimidate voters towards voting for their candidates, they further asserted that the security policies put in place to fight crime in the in the country were very weak. In Nigeria, Section 131(1) of the Electoral Act 2010 recommends options of conviction of up to 10 years, fine, or both for individuals guilty of threatening or kidnapping during elections. Section 364 of the Criminal Code Act stipulates that kidnapping is a felony, and those found guilty are to be convicted for a minimum of 10 years, while these policies are supposed to serve as deterrents and punitive measures for threats and kidnapping, their implementation has been very poor thus leading to a rise in the use of these tools by thugs, political candidates and political parties among others to influence the voting pattern or results of elections in their favour. The implementation of the various laws on threats and kidnapping may significantly reduce their occurrence as well as other related crimes during elections. (Krook and Sanín, 2016; Khakee, and Florquin, 2003; Gutiérrez, 2014).

\subsection{Education and Training of Electoral staff, Unimplemented Electoral Act and ERV}

Education is a major machinery that can be employed in curbing the incidence of ERV. Mass education of the electorates especially on the tenets of the democratic system of government and the electoral process tends to create a better understanding of the process. It also helps in reducing the chances of the eruption of violence during elections. Studies have also shown that in communities where a large percentage of residents are educated, there are lower chances of ERV as compared to areas that have a larger population of uneducated residents. Abess, Marcarthy, and Konneh, (2018) agree that adequate voter education has the potential of increasing citizens trust in the electoral process, increasing voter participation as well as ensuring that there is minimal violence during elections. He further noted that communities with effective public policies especially in the area of the provision of civic education for the members of the community will have higher chances of achieving peaceful and transparent elections. Cho, Connors, Fatima and Yalim, (2015) posit that the availability of electoral education not only increases voter turnout but also results in a lower number of invalidated votes during elections mainly because 
the electorates tend to understand the principles and practices of elections better with increased voter education. Booysen et al, (2015) elucidates the importance of training on the performance of electoral workers during elections, he notes that effective training helps electoral workers perform optimally during elections. The Nigerian scenario has shown that voter education amongst the masses was adjudged to be poor which is one of the major reasons why electoral violence is rampant as well as a large quantity of invalid votes during elections. Section 2 and 153 of the Electoral Act 2010 saddles INEC with the responsibility of carrying out voter education as a way of enlightening the public as well as reducing the incidence of electoral violence. The country's foremost electoral body, INEC cannot be said to have diligently created sufficient information of the electoral and democratic process to the masses, hence elections are characterized by violence and a large quantity of votes getting invalidated. The proper implementation of Section 2 and 153 of the electoral act 2010 may provide significant impacts on the incidence of electoral violence and invalidation of votes among other negative effects of poor voter education. Adequate training of electoral workers on the current best practices of electoral practices also has the possibility of improving the performance of electoral workers. (Krook and Sanín, 2016; Khakee, and Florquin, 2003; Gutiérrez, 2014).

\subsection{Vote buying, Policies and its impacts on ERV}

Vote buying takes different forms, each one, unique to the communities where it is perpetrated, however, characteristics such as exchange of services, materials or money for votes make vote buying similar across most climes. The act of vote buying is illegal in most democracies, however they have been said to be largely employed during elections in different countries. Most countries without proper implementation of the laws against vote buying usually experience more incidences of vote buying during elections. Jang and Chang, (2016) opined that vote buying reduces the transparency expected in a free and fair elections. They further asserted that the practice of vote buying is one of the key drivers of poverty amongst the masses as it encourages corruption within a country and may not have any significant effects on election outcomes. Finan, and Schechter, (2012) agree that vote buying is enabled by reciprocity where the votes of individuals are exchanged for money, goods or services etc. They further stated that vote buying is usually targeted at low income earners who are most likely to be influenced by the offers of those who seek to buy their votes; they also added that vote buying is popular in countries like Paraguay, Taiwan and Thailand amongst others. Vote buying in Nigeria has been a known phenomenon during elections for a long time. Votes are bought in exchange for money, favours as well as consumer items such as grains, salt, sugar and groundnut oil among others. In the Nigerian situation, vote buying is mostly targeted at low income communities, families, individuals and peer groups amongst others. Vote buying during elections in Nigeria is one of the major reasons why most elections are alleged to be compromised. The Section 130 and 131 of the Electoral Act 2010 states that a fine or prison sentence or both will be the penalty for vote buying. The non implementation of this section of the Electoral Act is believed to be one of the reasons why the act is alleged to be on the rise during elections. The strict implementation of this section may likely reduce the incidence of vote buying during elections as it has been shown to be effective in other climes. (Jang and Chang, 2016; Finan, and Schechter, 2012).

\subsection{Public office attraction, Desperation and ERV}

Nigeria is one of the countries where law makers and public officers who occupy electoral offices have enjoyed very high remuneration packages as compared to other countries in the world. It is alleged that it will take a minimum wage earner 38 years accumulated salary to match the monthly salary of a senator. The high remuneration for elective offices in Nigeria is adjudged one of the reasons why politicians are desperate to occupy elective offices and while employing the use of various degrees of violence to ensure they emerge victorious in elections. Uma and Eboh, (2013) agree that high remuneration of public officers in Nigeria is one of the major causes of violence during elections. They also opined that the high remuneration of public service workers may be one of the major catalysts of bribery and corruption in Nigeria. They recommended a cut in the remunerations as a way of making elective offices less attractive as this will reduce the desperation attached with the quest for public office, this will also help in ensuring that only people who want to serve will vie for public office. Another suggestion that has been proffered in grey literature; a poll carried out by Thisday newspaper on the July 20, 2017 sought people's opinions on a part time legislature as a way to cut costs of governance, most of the responders agreed that the adoption of part time legislation will reduce the cost of governance as well as reduce corruption in the country. (Uma and Eboh, 2013)

\section{Conclusion}

Empirical data has shown that elections in Nigeria are characterized by violence which is caused by a myriad of factors which includes but are not limited to the dearth of the application of modern technology to the election process, lack of adequate security, lack of independence of the country's electoral body, intimidation of electoral officers and voters through various violent means, lack of education among the electorates and electoral officers, 
vote buying and public service attraction due to the impression of high remuneration among others. The study also showed that there exists relevant policies and laws in the Electoral act and constitution that are supposed to address some of the major challenges that tend to enable ERV in the country, however the implementation of these laws and the punitive measures meant to dissuade key actors in the perpetration of ERV has not been effective. The data gathered from other climes where similar challenges are experienced showed that the implementation of the relevant policies meant to ensure the achievement of free, fair and safe elections may significantly address the cases of ERV in Nigeria.

\section{Recommendations}

\subsection{Adequate Health and Welfare Policies for Electoral Workers}

Since electoral workers are important in the successful conduct of free and fair elections, and there's a high possibility of them getting affected by ERV, the provision of an adequately planned and wholesome health and welfare policy will ameliorate the resultant effects of ERV on electoral workers while motivating them to work efficiently. This may also help in reducing the incidence of electoral fraud in favour of electoral candidates by electoral workers as proper welfare packages may reduce the chances of them accepting bribes from political parties and electoral candidates. The availability of an independent health care policy for electoral workers will further re-enforce the independence of the electoral bodies.

\subsection{Using Modern technology to curb ERV}

The data from this study shows that the deployment of modern technology especially in the areas of biometrics, collation and submission of electoral results has improved the electoral process as well as effectively reducing the chances of electoral fraud and ERV in countries where they have been applied. The application of modern technology in the Nigerian setting may also help in reducing the incidences of ERV if the right measures are adopted. While this provision is included in the current electoral bill waiting passage into law, it is imperative that the application be carried out properly with efficient implementation measures in place to scale up the productivity of the technology. Full implementation of all other existing laws backing the use of technology to curb ERV should be considered.

\subsection{Full implementation of relevant Security Laws and Reformation of Security Agencies}

The reformation of security agencies with the main aim of providing of adequate security during elections will help in increasing the possibility of achieving more transparent elections. Full implementation of all current laws and legal provisions on the conviction of those who perpetrate acts leading to electoral malpractice or ERV such as vote buying, murder, threatening of individuals and kidnapping among others will serve as a deterrent to others. The application of real-time surveillance through the use of close circuit television (CCTV) cameras will further improve the effectiveness of the security agencies.

\subsection{Independent Electoral Bodies and Transparency during Elections}

Section 158 of the Constitution of the Federal Republic of Nigeria legitimises the full independence of the Nation's electoral body. The full implementation of that section of the constitution will ensure true independence of the electoral body. Additional legislation should be put in place to ensure that the Chief Executive officers of Electoral bodies are selected internally as opposed to the current practice of Presidential appointment and legislative confirmation.

\subsection{Education, Efficient Electoral staff and Transparent Elections}

Section 2 and 153 of the electoral act 2010 mandates INEC to provide adequate civic education prior to elections. The proper implementation of this section of the Electoral Act will ensure adequate provision of civic education to the populace thus improving their understanding of the electoral process. A collaboration of INEC and other government organisations such as National Orientation Agency (NOA) and Non Governmental Organisations (NGOs) will help in ensuring that adequate tactics are employed in the successful dissemination of important electoral education especially to low income areas and rural areas among others.

\subsection{Public office attraction}

The high remuneration for Public office holders is one of the major reasons why it is deemed attractive and has a lot of politicians resorting to violence as a means of winning elections, this is mostly because it is one of the highest in the whole world. While there are no current legislations addressing the issue of high remuneration, there is an urgent need to cut down on the remuneration of elected officials, other options such as part time legislation should be considered as a means of reducing the cost of running the government. New legislation to the effect of reduction of remuneration and other expensive provisions for law makers should be considered as this might also help in reducing the level of corruption currently experienced in the country. 


\section{References}

Abess, G., Marcarthy, J. and Konneh, A. (2018) Final Evaluation of the Project: Standing Together for Free, Fair and Peaceful Elections in Sierra Leone [Online] Available from: https://webcache.googleusercontent.com/search?q=cache:KGhgiwyghAUJ:https://www.sfcg.org/wpcontent/uploads/2018/11/SLE505-Final-DFID-Project-Evaluation-.pdf $+\& c d=1 \& h \mathrm{l}=\mathrm{en} \& \mathrm{ct}=\mathrm{clnk} \& \mathrm{gl}=\mathrm{ng}$ [Accessed: 9th November, 2018]..

Bardall, G. (2013) Gender-Specific Election Violence: The Role of Information and Communication Technologies. Stability: International Journal of Security and Development,[Online] 2(3) Available from: http://doi.org/10.5334/sta.cs [Accessed: 9th November, 2018]

Bogdan, R. and Biklen, S. (1997) Qualitative research for education.[Online] Boston, MA: Allyn \& Bacon. Available http://www.academia.edu/download/31190365/EDU7900_Qualitative_Research_for_Education.pdf [Accessed: 9th November, 2018]

Boonlue, N, (2015)Local Politics and Democracy in Thailand. Procedia economics and finance [Online] Available from: https://www.sciencedirect.com/science/article/pii/S2212567115005316 [Accessed: 9th November, 2018]

Booysen et al (2015) Journal of African Elections Special Issue South Africa's 2014 Elections. [Online] Available from:. https://www.eisa.org.za/pdf/JAE9.2.pdf [Accessed: 9th November, 2018]

Carr, L. (1994) The strengths and weaknesses of quantitative and qualitative research: what method for nursing?. Journal of advanced nursing, [Online] 20(4). Available from: https://onlinelibrary.wiley.com/doi/abs/10.1046/j.1365-2648.1994.20040716.x [Accessed: 9th November, 2018]

Castiglione, D. and Warren, M. (2006) Rethinking democratic representation: Eight theoretical issues. Trabalho apresentado no Workshop Rethinking Democratic Representation. University of British Columbia [Online]. Available from: http://citeseerx.ist.psu.edu/viewdoc/download?doi=10.1.1.565.9652\&rep=rep1\&type=pdf [Accessed: 9th November, 2018]

Cho, S.Y., Connors, E., Fatima, F. and Yalim, U. (2015) Preventing Post-Election Violence Based on the Kenyan Experience. [Online] Available from:https://www-cdn.law.stanford.edu/wp-content/uploads/2016/07/ChoConnors-Fatima-Yalim-Preventing-Post-Election-Violence-Based-on-the-Kenyan-Experience.pdf [Accessed: 9th November, 2018]

Condra et al (2016) Damaging democracy? Security provision and turnout in Afghan elections. Economics \& Politics. [Online] Available from: https://onlinelibrary.wiley.com/doi/abs/10.1111/ecpo.12128 [Accessed: 9th November, 2018]

Dwomoh, G., Owusu, E. and Addo, M. (2013) Impact of occupational health and safety policies on employees' performance in the Ghana's timber industry: Evidence from Lumber and Logs Limited. [Online] International Journal of Education and Research, 1(12). Available from: http://ijern.com/journal/December2013/38.pdf [Accessed: 9th November, 2018]

Finan, F. and Schechter, L. (2012) Vote - buying and reciprocity. Econometrica,[Online] 80(2). Available from: http://pseweb.eu/ydepot/semin/texte0910/FIN2010VOT.pdf [Accessed: 9th November, 2018]

Franco, L.M., Bennett, S., Kanfer, R. and Stubblebine, P. (2004) Determinants and consequences of health worker motivation in hospitals in Jordan and Georgia. Social science \& medicine, [Online] 58(2) Available from: https://www.researchgate.net/publication/9019568_Determinants_and_Consequences_of_Health_Worker_ Motivation_in_Hospitals_in_Jordan_and_Georgia [Accessed: 9th November, 2018]

Gelb, A. and Diofasi, A. (2016) Biometric Elections in Poor Countries: Wasteful or a Worthwhile Investment? Review of Policy Research. [Online] Available from: https://onlinelibrary.wiley.com/doi/abs/10.1111/ropr.12329 [Accessed: 9th November, 2018]

Gutiérrez, S. (2014) Citizens in fear: political participation and voting behaviour in the midst of violence. [Online] Available from: http://dukespace.lib.duke.edu/dspace/bitstream/handle/10161/9038/LeyGutierrez_duke_0066D_12531.pdf;s equence $=1$ [Accessed: 9th November, 2018]

Hoglund and Jarstad (2010) Strategies to Prevent And Manage Electoral Violence: Considerations for Policy [Online] Available from: https://www.africaportal.org/documents/5447/policy_practice11.pdf [Accessed: 9th November, 2018]

Jang, C.L. and Chang, C.P. (2016) Vote Buying and Victory of Election: The Case of Taiwan. Prague Economic Papers. [Online] 2016(5) Available from:. file:///C:/Users/Tochi/Downloads/576.pdf [Accessed: 9th November, 2018]

Jinadu, L. (1997)Matters Arising: African Elections and the Problem of Electoral Administration [Online] Available from: https://www.jstor.org/stable/23489771 [Accessed: 9th November, 2018]

Khakee, A. and Florquin, N. (2003). Kosovo and the gun: A baseline assessment of small arms and light weapons 
in Kosovo. Geneva: Small Arms Survey. [Online] Available from: http://www.academia.edu/download/3249373/2003-06_SR_No3_Kosovo_and_the_Gun.pdf [Accessed: 9th November, 2018]

Krook, M.L. and Sanín, J.R. (2016) Gender and political violence in Latin America. Política y gobierno,[Online] 23,(1) Available from:: http://www.mlkrook.org/pdf/pyg_2016.pdf [Accessed: 9th November, 2018]

Kühne, W. (2010. The role of elections in emerging democracies and post-conflict countries. International Policy Analysis, 1. [Online] Available from: http://library.fes.de/pdf-files/iez/07416.pdf\# [Accessed: 9 th November, 2018]

Lopez-Pintor, R (2000) Electoral Management Bodies as Institutions Of Governance. [Online] Available from: http://www.eods.eu/library/UNDP.Electoral\%20Management $\% 20$ Bodies\%20as\%20Institutions $\% 20$ of $\% 20$ Governance.pdf [Accessed: 9th November, 2018]

Lundberg, O. (2009) How do welfare policies contribute to the reduction of health inequalities?. Eurohealth, [Online] 15(3). Available from: http://www.lse.ac.uk/LSEHealthAndSocialCare/pdf/eurohealth/VOL15no3/Lundberg_welfare_policies.pdf [Accessed: 9th November, 2018]

Mamabolo, L. (2009) The experiences of registered nurses involved in termination of pregnancy at Soshanguve Community Health Centre (Doctoral dissertation). [Online] Available from: http://uir.unisa.ac.za/handle/10500/1962 [Accessed: 9th November, 2018]

Mancini et al (2013) New technology and the prevention of violence and conflict. [Online] Available from: https://papers.ssrn.com/sol3/papers.cfm?abstract_id=2902494 [Accessed: 9th November, 2018]

Martin-Shields, C. (2013) Inter-ethnic Cooperation Revisited: Why mobile phones can help prevent discrete events of violence, using the Kenyan case study. Stability: International Journal of Security and Development, [Online] 2(3). Available from: https://www.stabilityjournal.org/article/view/sta.cu/158/ [Accessed: 9th November, 2018]

Mutahi, P. and Kimari, B. (2017) The Impact of Social Media and Digital Technology on Electoral Violence in Kenya. IDS [Online] Available from: https://opendocs.ids.ac.uk/opendocs/handle/123456789/13159 [Accessed: 9th November, 2018]

Okello, E.O. (2006) Guaranteeing the independence of election management bodies in Africa: A study of the electoral commissions of Kenya and South Africa (Doctoral dissertation, University of Pretoria). [Online] Available from: https://repository.up.ac.za/handle/2263/1227 [Accessed: 9th November, 2018]

Pandey, P. and Pandey, M. (2015) Research methodology: Tools and techniques. [Online] Available from: https://www.euacademic.org/BookUpload/9.pdf [Accessed: 9th November, 2018]

Pluye, P. and Hong, Q. (2014) Combining the power of stories and the power of numbers: Mixed methods research and mixed studies reviews. Annual review of public health, [Online] Available from: https://www.annualreviews.org/doi/abs/10.1146/annurev-publhealth-032013-182440 [Accessed: 9th November, 2018]

Rahman, M. (2017) The Advantages and Disadvantages of Using Qualitative and Quantitative Approaches and Methods in Language" Testing and Assessment" Research: A Literature Review. [Online] Available from: Journal of Education and Learning, 6(1). [Accessed: 9th November, 2018]

Section 2 and 153 of the Nigerian electoral act 2010 [Online] Available from: https://www.lawyard.ng/wpcontent/uploads/2016/01/ELECTORAL-ACT-2010.pdf [Accessed: 9th November, 2018]

Shenga, C. and Pereira, (2019) The Effect of Electoral Violence on Electoral Participation in Africa. Cadernos de Estudos Africanos, [Online] (38) Available from: https://journals.openedition.org/cea/4459 [Accessed: 9th November, 2020]

Thomas, R. (2003) Blending qualitative and quantitative research methods in theses and dissertations. Corwin Press. [Online] Available from: https://methods.sagepub.com/book/blending-qualitative-quantitativeresearch-methods-in-theses-and-dissertations. [Accessed: 9th November, 2018]

Thomassen, J.J. and Denters, S.A.H.(2010) How Democracy Works: Political Representation and Policy Congruence in Modern Societies: Essays in Honour of Jacques Thomassen. Amsterdam University Press. [Online] Available

from: https://books.google.com/books?hl=en\&lr=\&id=ft5thLW8JnMC\&oi=fnd\&pg=PA7\&dq=1.\%09Democracy +Works:+Political+representation+and+policy+congruence+in+modern+societies.+Edited+by+Martin+Ros ema, + Bas+Denters + and + Kess + Aarts\&ots=VB8wwI6sHG\&sig=n6PWX_QiAVEskuHpESuAfM7m_YI [Accessed: 9th November, 2018]

Torrance, H. (2012) Triangulation, respondent validation, and democratic participation in mixed methods research. Journal of mixed methods research, [Online] 6(2). Available from: https://journals.sagepub.com/doi/abs/10.1177/1558689812437185[Accessed: 9th November, 2018].

Uma, K.E. and Eboh, F.E. (2013) Corruption, Economic development and Emerging markets: Evidence from 
Nigeria. Asian Journal of Management Science and Education,. [Online] Available from: https://citeseerx.ist.psu.edu/viewdoc/download?doi=10.1.1.1039.7674\&rep=rep1\&type=pdf [Accessed: 9th November, 2018].

Venkatesh, V., Brown, S.A. and Bala, H. (2013) Bridging the qualitative-quantitative divide: Guidelines for conducting mixed methods research in information systems. MIS quarterly. [Online] Available from: https://www.jstor.org/stable/43825936 [Accessed: 9th November, 2018].

Verjee, A., Kwaja, C. and Onubogu, O. (2018) Nigeria's 2019 Elections: Change, Continuity, and the Risks to Peace. United States Institute of Peace (USIP) Special Report. [Online] Available from: https://www.usip.org/sites/default/files/2018-09/sr_429_verjee_et_al_final.pdf [Accessed: 9th November, 2018].

Warren, M.E. (1999). Democracy and trust. Cambridge University Press. [Online] Available from: https://books.google.com.ng/books?hl=en\&lr=\&id=KepLD0MXbhYC\&oi=fnd\&pg=PR7\&dq=democracy\& ots=AXImUpsptt\&sig=HWNyhI45DKsiAu3P7Fp40bSflE\&redir_esc $=\mathrm{y} \# \mathrm{v}=$ onepage $\& \mathrm{q}=\mathrm{democracy} \& \mathrm{f}=\mathrm{fal}$ se [Accessed: 9th November, 2018]. 